
\title{
25 Research Soure \\ Recreational Harvest of Sharks and Rays in Western Australia is only a Minor Component of the Total Harvest
}

Matias Braccini ( $\triangle$ Matias.Braccini@dpird.wa.gov.au )

Department of Primary Industries and Regional Development

Eva Lai

Department of Primary Industries and Regional Development

Karina Ryan

Department of Primary Industries and Regional Development

Stephen Taylor

Department of Primary Industries and Regional Development

\section{Research Article}

Keywords: elasmobranch, conservation, management, fisheries, catch reconstruction

Posted Date: February 23rd, 2021

DOI: https://doi.org/10.21203/rs.3.rs-225321/v1

License: () (1) This work is licensed under a Creative Commons Attribution 4.0 International License. Read Full License 


\section{Abstract}

Sharks and rays are of global conservation concern with an increasing number of species at risk of extinction, mostly attributed to overfishing by commercial fishing. Their recreational harvest is poorly known but it can be of similar magnitude to the commercial harvest in some regions. We quantified the recreational harvest of sharks and rays in Western Australia, a region with a marine coastline of $>20,000$ $\mathrm{km}$. We recorded 33 species/taxonomic groups but the harvest was dominated by dusky and bronze whalers, blacktip reef shark, gummy shark, Port Jackson shark, wobbegongs, and rays and skates. Most species caught were released (85\% of all individuals), although gummy and whiskery sharks were typically retained. There was a clear latitudinal gradient of species composition with tropical and subtropical species of the genus Carcharhinus dominating in the north and temperate species of the families Triakidae, Carcharhinidae, Heterodontidae and Rajidae dominating in the south. The recreational harvest was negligible compared with commercial landings. The newly available time series data can be incorporated into stock assessments to allow the quantification of recreational fishing mortality of shark and ray species and therefore comply with state, national and international initiatives for their conservation and sustainable management.

\section{Introduction}

Recreational fishing has numerous socio-economic benefits and the vast majority of people that fish today do so recreationally ${ }^{1,2}$. Although recreational fishing accounts for only $10 \%$ of global fish harvest ${ }^{3}$, it can exceed the commercial harvest in some cases ${ }^{4}$. Recreational fishing can have negative impacts on fish populations and ecosystems (e.g. ${ }^{5}$ ) but these impacts have been largely ignored ${ }^{1}$. Despite being implicated in the decline of some fish populations, recreational fishing is rarely considered a threat ${ }^{5}$, in part because obtaining robust estimates of recreational harvest is difficult for rare species or may not account for post-release mortality (PRM) ${ }^{6}$.

International Union for Conservation of Nature Red List Criteria indicate one quarter of shark and ray species are threatened with extinction due to overfishing ${ }^{7}$, with several species listed under international agreements aimed at regulating wildlife trade and protecting endangered migratory species. Due to their intrinsic low productivity, sharks and rays cannot withstand high levels of fishing pressure in the long term so they are particularly vulnerable to over-exploitation and susceptible to population collapse if not properly managed ${ }^{8}$. Commercial fishing is considered the main threat to shark and ray populations ${ }^{9}$ and population assessments are typically limited to evaluating commercial catches (e.g. ${ }^{10,11}$ ). Although catches of sharks and rays from recreational fishing are generally small compared with catches from commercial fishing, in some cases the recreational harvest can be considerable and even of similar magnitude or higher than commercial catches $\left(\right.$ e.g. ${ }^{12}$ ). For most regions, however, the potential impact from recreational fishing on shark and ray populations is unknown as reliable time series are not available 2 . 
Recreational fishing has been a popular activity in Western Australia for many years with an estimated of 2.82 million fish from $>180$ species caught by boat-based recreational fishers in 2017-18 ${ }^{13}$. The most sought-after species are invertebrates, such as western rock lobster (Panulirus cygnus) and blue swimmer crab (Portunus armatus), and scalefish, such as school whiting (Sillago schomburgkii, bassensis \& vittata), Australian herring (Arripis georgianus) and pink snapper (Chrysophrys auratus). Sharks and rays are rarely targeted by recreational fishers, contributing a minor component of their harvest ${ }^{13}$. In contrast, sharks have been targeted by commercial fishers in Western Australia since the early 1940 s $^{14,15}$ but current assessments do not take into account the recreational harvest as time series are not available ${ }^{16}$.

The consequences of ignoring recreational harvest in stock and ecosystem assessments are unclear (e.g. $\left.{ }^{17}\right)$. Hence, quantifying recreational harvest is essential to account for potential impacts from this sector and to improve understanding of the impact of removals from all fishing sectors on the marine environments. Data collected from monitoring marine recreational fisheries in Western Australia, which encompass $>20,000 \mathrm{~km}$ of coastline across tropical and temperate bioregions, provide a unique case study for quantifying the recreational harvest of this diverse marine taxon. The current study aims to characterise the species composition and relative abundance from catches of private- and charter-boat recreational fishers and reconstruct the time series of annual recreational harvest. This study will improve conservation and management arrangements for elasmobranch species (sharks and rays), and has wider benefits for population assessments of other species where recreational harvests need to be quantified.

\section{Results}

In total, 33 elasmobranch species (or species groups) were identified although the recreational harvest was dominated by dusky whaler (Carcharhinus obscurus), rays \& skates, blacktip reef (C. melanopterus), Port Jackson, and gummy sharks, bronze whaler ( $C$. brachyurus), and wobbegongs (Table 2 ). For some species there was a very small number of observations. Most caught individuals (85\%) were released although hound sharks such as gummy and whiskery sharks were typically retained (Table 2).

There were clear differences in species composition among bioregions (Fig. 2) with the nMDS showing a north-to-south gradient, which corresponds to the species' general distribution (Fig. 3). The species characterising the main differences among bioregions are shown in Table S 1. At the bioregional extremes, in the North Coast and South Coast bioregions, differences in catch composition were due to the predominance of tropical and subtropical species of the genus Carcharhinus in the North Coast, such as reef, pigeye (C. amboinensis), lemon (Negaprion acutidens), sandbar (C. plumbeus) and tiger (Galeocerdo cuvier) sharks, and temperate species in the South Coast, such as gummy and Port Jackson sharks and bronze whaler (Fig. 2).

As expected from the reconstruction method, which scaled harvests by the residential population size, recreational harvest increased through time (Fig. 4). The reconstructed annual recreational harvest increased from 14 tonnes ( 5 and 28 tonnes for the Low and High scenarios, respectively) in the early 1940s to 83 tonnes (30 and 160 tonnes for the Low and High scenarios, respectively) in 2017-18. Dusky and 
bronze whalers, and gummy and blacktip reef sharks had the highest annual harvests ( $>10$ tonnes in 201718) whereas for most other species, recreational annual harvests were negligible ( $<1$ tonne in 2017-18). The overall recreational harvest was negligible compared to the commercial catch reported in statutory catch and effort returns (i.e. landings) and the commercial catch reconstructed by ${ }^{18}$, which accounts for illegal and unreported catches, and discards (Fig. 5).

\section{Discussion}

The reconstructed time series indicate that recreational harvest of elasmobranch species is low and represents a small component of the total mortality of sharks and rays in Western Australia compared with commercial extractions. The elasmobranch harvest from commercial and recreational fisheries reveal a contrasting trend. At the historic peak, the commercial shark fisheries of Western Australia (Northern Shark Fisheries and Temperate Demersal Gillnet and Demersal Longline Fisheries) reported annual shark and ray landings of $>1,300$ and $>1,800$ tonnes, respectively ${ }^{19,20}$. The contemporary commercial landings of sharks and rays $(<1,000$ tonnes) is lower than in previous decades due to management arrangements aimed at ensuring the sustainability of the fisheries. In contrast, the largest annual recreational harvest was for 201718 at 83 tonnes (base case scenario), i.e. $<2.7 \%$ of the peak of commercial landings. At an assumed average weight of $5 \mathrm{~kg}$, these equates to $<17,000$ individuals. Based on a nation-wide survey, which included screening from the general population and a 12-month phone-diary survey in 2000/01 21, an estimated 24,000 sharks and rays were harvested in Western Australia and 82\% of the harvest was released. In contrast, several million individuals of scalefish species are harvested annually in Western Australia, most of which are retained ${ }^{13}$.

In comparison to other Australian states (Victoria, New South Wales and South Australia), sharks are less of a target for game fishers in Western Australia ${ }^{22,23}$. Whaler and tiger sharks have been tagged and released by recreational game fishers in Western Australia, particularly in Exmouth and Broome where game fishing for marlin and other billfish is popular ${ }^{24}$. However, our findings are in agreement with the broader Australian national survey, indicating that sharks and rays in Western Australia are not the primary target species for most recreational fishers and when captured, they are mostly $(85 \%)$ released.

Accurately identifying the recreational catch is difficult, particularly for carcharhinids that are taxonomically very similar ${ }^{25}$, and for sharks that are released prior to landing. In the current study, the use of species identification guides and trained telephone interviewers helped recreational fishers to recall information on their catches. Nevertheless, mis-identification could have occurred for some species. Furthermore, the reconstruction of shore-based recreational fishing was done by scaling the harvest from private-boat anglers. This is a limitation to the current study as it assumes that both sectors have the same shark and ray species composition. To improve the current harvest estimates, targeted shore-based surveys are therefore required as some elasmobranch species, such as wedgefish (Rhinidae) and guitarfish (Rhinobatidae and Glaucostegidae) have been caught and released by shore-based anglers (M. Braccini pers. obs.) but did not occur in the reported private-boat harvest. 
In this study, a conservative approach to PRM was considered to account for the mortality of sharks and rays released by recreational fishers related to capture stress, damage due to hooks or terminal tackle, or poor handling practices ${ }^{2}$. Shark depredation is a common issue encountered by recreational fishers in some regions of Western Australia ${ }^{13,26}$ and the PRM values used in this study would also account for this 'cryptic' source of mortality. However, further research is warranted to determine effective ways for recreational fishers to handle and release sharks and rays to aid in their survival (e.g. ${ }^{27}$ ). Similarly, average weight information was only available for a subset of species. Hence, for those species that attain large sizes, such as tiger shark, hammerheads and sawfishes, future research should aim at collecting average weight data to minimize underestimating the extent of the recreational harvest of these species.

The species composition of the recreational harvest varied across bioregions, where carcharhinids dominated in tropical and subtropical waters and more temperate species from a range of families dominated in the south. Similarly, on the east coast of Australia several species of the genus Carcharhinus dominated the catch composition of recreational fishers in the north (e.g. $\left.{ }^{28}\right)$ whereas the catch composition in the south comprised of mostly temperate species from a range of different families (e.g. $29,30)$.

The historically low recreational harvest in Western Australia is unlikely to have had a substantial impact on shark and ray stocks overall. For other stocks and regions, recreational harvesting has had considerable impacts on shark populations, and can be of similar magnitude as commercial shark fishing. For example, the greynurse shark (Carcharias taurus) was almost extirpated from the east coast of Australia due to mostly recreational spearfishing ${ }^{31}$ and the recreational harvest of large coastal sharks in the Gulf of Mexico and east coast of the US would be larger than the commercial harvest ${ }^{12}$. In contrast, commercial shark and ray landings in Western Australia is $>10$ times larger than the recreational harvest, and, for most of the commonly harvested species by recreational fishers, there have been substantial management measures implemented to ensure sustainability ${ }^{20}$.

The present study estimated the recreational harvest of sharks and rays in Western Australia, reconstructing time series required for assessing these stocks to comply with state, national and international initiatives for the conservation and sustainable management of sharks and rays. By incorporating the species-specific harvest time series into stock assessments, this newly available information would allow quantifying the impact of recreational fishing on shark and ray populations in Western Australia. However, this effect is expected to be negligible as the recreational harvest is only a fraction of the commercial landings.

\section{Methods}

\section{Data sources.}

Quantification of the recreational harvest utilised data collected from boat-based recreational fishing surveys and tour operator returns (charter logbooks) across the multiple bioregions of Western Australia 
(Fig. 1), and the scaling of these data back to 1941, which is considered the start of shark fishing in the State ${ }^{14,15}$. Recreational fishers in Western Australia are required to possess a Recreational Boat Fishing Licence which provides a cost-effective sampling frame for recreational fishing surveys. Biennial statewide recreational fishing surveys have been conducted in Western Australia in 2017/18 (September 2017 to August 2018), 2015/16 (September 2015 to August 2016), 2013/14 (May 2013 to April 2014) and 2011/12 (March 2011 to February 2012) ${ }^{13}$. A random sample of Recreational Boat Fishing licence holders were selected for an initial Screening Survey to identify intending fishers for recruitment into a 12-month PhoneDiary Survey. Survey participants were given diary kits containing a welcome letter, species identification guide ${ }^{32}$, fishing location guide ${ }^{33}$ and diary card. After receiving the diary kits, a brief diary explanation was provided by trained interviewers, and participants were encouraged to use the diary card to record fishing effort (start and end times of a fishing event), catch (numbers by species, both retained and released), location, method and trip time (boat launched and retrieval times) of every fishing event during the 12month period. Survey participants were then contacted regularly by interviewers during the 12-month period to collect their fishing information. Further details about the survey design, annual estimates and measure of uncertainty for elasmobranch species are available from ${ }^{13,34-36}$.

Reporting of effort and catch data from charter-boat recreational fishing have been monitored with mandatory Tour Operator Returns (charter logbooks) in Western Australia since 2001. These data include fishing effort (number of clients on charter boat), catch (numbers by species, both retained and released) and location ${ }^{37}$. For consistency with time series reconstructions (see below), only those years when the statewide surveys were conducted were considered in this study. As the Tour Operator data are from an assumed census, there are no measures of uncertainty associated with aggregated catch.

\section{Data analyses.}

Data were adjusted to account for known sources of bias and to improve accuracy of estimated recreational harvest based on the following steps: 1) proportional allocation of catches from generic to specific taxa, 2) adjustment of estimated catch from private-boat recreational fishing to account for shorebased recreational fishing, 3) adjustment of estimated catch to account for PRM, and 4) conversion of estimated catch in numbers to weights. Following data adjustments, the recreational harvest time series were reconstructed. All analyses were done using the statistical package $\mathrm{R}^{38}$. The computer code developed for data adjustments and analyses can be accessed at https://github.com/JuanMatiasBraccini/Git_Stock.assessments/blob/master/Catch.recons.Recreational.R.

\section{Reapportioning of generic taxa.}

Both the statewide surveys and Tour Operator Returns have some records for generic taxa that do not discriminate between species (e.g. 'whaler shark', 'other shark' or 'hammerhead'). Therefore, for both data sets, the estimated harvest of sharks reported as 'whaler shark' was reapportioned using the overall proportion of whaler sharks reported at a species level by bioregion and year. Similarly, the estimated 
harvest of sharks reported as 'other shark' were reapportioned using the proportion of sharks reported to the species level. The estimated harvest of 'hammerhead' was reapportioned into scalloped (Sphyrna lewini) or smooth (S. zygaena) hammerhead according to the bioregion in which the harvest was reported based on the spatial distribution of these two species ${ }^{39}$. Although great hammerhead (S. mokarran) also occurs in northern Western Australia, they are much less common than scalloped hammerhead so they were not considered in the reapportioning. Hence, the 'hammerhead' harvest reported in the Gascoyne and North Coast bioregions was allocated to scalloped hammerhead whereas the harvest reported in the West Coast and South Coast bioregions was allocated to smooth hammerhead. Finally, records of bull shark $(C$. leucas) were considered to be pigeye shark (C.amboinensis) due to their morphological similarities but much higher abundance of pigeye shark in the study area ${ }^{40}$.

\section{Calculation of shore-based recreational fishing.}

Currently, there are no year- and region-specific estimates of shore-based recreational fishing harvest. Therefore, the estimated harvest from private-boat surveys was adjusted to account for shore-based recreational fishing using a private-boat to shore-based ratio (1:0.96) available for 2000-01 for elasmobranch species across Western Australia (DPIRD unpublished data). Thus, for each statewide survey year, shore-based recreational fishing harvest was calculated as 0.96 of the estimated catch of each elasmobranch species from private-boat recreational fishing.

\section{Accounting for post-release mortality.}

To account for PRM, species-specific PRM from line fishing was obtained from the literature. This information was only available for gummy (Mustelus antarcticus), school (Galeorhinus galeus), Port Jackson (Heterodontus portusjacksoni) and hammerhead sharks, and rays and skates ${ }^{41-45}$. For species without available estimates, a conservative value of $30 \%$ was assumed (Table 2). The estimated harvest for each species was therefore the sum of the retained catch and the product of the released catch with the assumed PRM. This process was repeated for each year for estimated catches from both the statewide surveys and charter logbooks.

\section{Conversion of numbers to weights.}

Average weights for species retained by private-boat recreational fishers were determined from boat ramp recreational fishing surveys conducted in 2011/12, 2013/14, 2015/16 and 2017/18 ${ }^{46}$. For elasmobranch species, average weights were available for gummy, whiskery (Furgaleus macki) and whaler sharks, wobbegongs, and rays and skates. Hence, for requiem (with the exception of nervous and sliteye sharks), hammerhead and lamnid sharks, and species of the orders Orectolobiformes and Rhinopristiformes without available estimates, the average weight for whaler sharks was used whereas the average weight for gummy shark was used for the remaining species without available estimates (Table 2). For each species, 
an average weight across all survey years was applied to the estimated total harvest (the sum of privateboat, shore-based and charter-boat catches). Given differences in the reliability of estimated catches across statewide survey years ${ }^{13}$, higher credence was given to estimates with lower relative standard error (RSE) by calculating an average weight, weighted by 1/RSE.

\section{Reconstruction of time series.}

For each species, the calculated average annual harvest (in weight) across survey years was then multiplied by a relative time series of residential population size and an estimated participation rate in recreational fishing (29.8\%), which corresponds to the average participation rate between 2009-10 and 2018-19 ${ }^{47}$. The relative time series of residential population size was obtained by dividing the Estimated Residential Population of Western Australia between 1941 and 2018 (Australian Bureau of Statistics, https://www.abs.gov.au, accessed 25 November 2019) by 2011. The year 2011 was chosen because it was the first year of the statewide surveys. Sensitivity tests were done to test the assumptions made on average weights and PRM using 'high' and 'low' catch reconstruction scenarios (Table 1). Total shark and ray catches in WA (recreational and commercial) were plotted to provide a perspective of the reconstructed recreational harvest in relation to total extractions. Two time series of commercial shark and ray catches were presented: those reported in statutory catch and effort returns (i.e. landings only) and those reconstructed by ${ }^{18}$ which also account for illegal and unreported catches and discards.

\section{Patterns in species composition.}

To determine patterns in species composition among bioregions and between private- and charter-boat fishing, multivariate analyses were done using the 'vegan' package ${ }^{48}$. Non-metric multidimensional scaling (nMDS) on squared-root transformed data and Bray-Curtis dissimilarities was used to collapse the multivariate species composition into two dimensions. Similarity Percentage (SIMPER) Analysis was used to determine the contribution of each species to the dissimilarity between bioregions.

\section{Declarations}

\section{Data Availability}

Data reported in this paper are archived in the Western Australian Department of Primary Industries and Regional Development Repository.

\section{Acknowledgements}

We thank all the private-boat recreational fishers who participated in the surveys and staff from the Survey Research Centre (Edith Cowan University) for coordinating and conducting the statewide surveys. We also thank all the Tour Operators who completed logbooks for charter-boat recreational fishing and DPIRD staff 
for providing these data. Funding was provided by the Department of Primary Industries and Regional Development of Western Australia.

\section{Author Contributions}

M.B. initiated the study, conducted the analyses and wrote the first draft of the paper. E.L., K.R. and S.T. run the recreational fishing surveys, collated the data and provided extensive input to the first draft.

\section{Competing interests}

The authors declare no competing interests.

\section{Use of experimental animals and human participants}

This research was approval by the Edith Cowan University Human Research Ethics Committee (2010-6146). All survey interviews were conducted by the Edith Cowan University Survey Research Centre in accordance with human research ethics, guidelines and research protocols. Informed consent was obtained from all respondents, with parent and/or legal guardian consent for licensed fishers under 18 years. This research relied on self-reporting of catch by recreational fishers and no sharks were directly used in this study.

\section{References}

1. Arlinghaus, R. et al. Governing the recreational dimension of global fisheries. Proc. Natl. Acad. Sci. U. S. A. 116, 5209-5213 (2019).

2. Gallagher, A. J., Hammerschlag, N., Danylchuk, A. J. \& Cooke, S. J. Shark recreational fisheries: Status, challenges, and research needs. Ambio 46, 385-398 (2017).

3. Cooke, S. \& Cowx, I. The role of recreational fishing in global fish crises. Bioscience 54, 857-859 (2004).

4. McPhee, D., Leadbitter, D. \& Skilleter, G. Swallowing the bait: is recreational fishing ecologically sustainable? Pacific Conserv. Biol. 8, 40-51 (2002).

5. Cooke, S. J. et al. Angling for endangered fish: Conservation problem or conservation action? Fish Fish. 17, 249-265 (2016).

6. Kyne, P. \& Feutry, P. Recreational fishing impacts on threatened river sharks: A potential conservation issue. Ecol. Manag. Restor. 18, 209-213 (2017).

7. Dulvy, N. K. et al. Extinction risk and conservation of the world's sharks and rays. Elife 3, e00590e00590 (2014).

8. Walker, T. I. Can shark resources be harvested sustainably? A question revisited with a review of shark fisheries. Mar. Freshw. Res. 49, 553-572 (1998). 
9. Field, I., Meekan, M., Buckworth, R. \& Bradshaw, C. Susceptibility of sharks, rays and chimaeras to global extinction. Adv. Mar. Biol. 56, 275-363 (2009).

10. Punt, A. E. \& Walker, T. I. Stock assessment and risk analysis for the school shark (Galeorhinus galeus) off southern Australia. Mar. Freshw. Res. 49, 719-731 (1998).

11. Walker, T. I. Stock assessments of the gummy shark, Mustelus antarcticus Gunther, in Bass Strait and off South Australia. in Population Dynamics for Fisheries Management (ed. Hancock, D. A.) 173-187 (Australian Government Printing Service, 1994).

12. Cortes, E., Brooks, L. \& Scott, G. Stock Assessment of large coastal sharks in the U.S. Atlantic and Gulf of Mexico. in Sustainable Fisheries Division Contribution SFD-2/03- 1771-63 (National Oceanic and Atmospheric Administration, National Marine Fisheries Service, Southeast Fisheries Science Center, Panama City, United States of America, 2002).

13. Ryan, K. et al. Statewide survey of boatbased recreational fishing in Western Australia 2017/18. (2019).

14. Simpfendorfer, C. \& Donohue, K. J. Keeping the fish in 'fish and chips': research and management of the Western Australian shark fishery. Mar. Freshw. Res. 49, 593-600 (1998).

15. Whitley, G. P. Preliminary report on the long line fishery at Bunbury, W.A. Unpublished report, 9 pp (available from Western Australian Marine Research Laboratories: North Beach.). (1943).

16. Braccini, M., Blay, N., Hesp, A. \& Molony, B. Resource assessment report temperate demersal elasmobranch resource of Western Australia. (2018).

17. Zeller, D., Darcy, M., Booth, S., Lowe, M. K. \& Martell, S. What about recreational catch?. Potential impact on stock assessment for Hawaii's bottomfish fisheries. Fish. Res. 91, 88-97 (2008).

18. Braccini, M., Kangas, M., Jaiteh, V., Wakefield, C. \& Newman, S. Quantifying the unreported and unaccounted domestic and foreign commercial catch of sharks and rays in Western Australia to improve threatened species assessments. Ambio DOI:10.1007/s13280-020-01495-6 (2021).

19. Molony, B., McAuley, R. B. \& Rowland, F. Northern shark fisheries status report: statistics only. in Status reports of the fisheries and aquatic resources of Western Australia 2012/13: The State of the Fsheries (eds. Fletcher, W. J. \& Santoro, K.) 216-217 (Department of Fisheries, Perth, Western Australia, 2013).

20. Braccini, M. \& Blay, N. Temperate demersal gillnet and demersal longline fisheries recource status report 2018. in Status Reports of the Fisheries and Aquatic Resources of Western Australia 2016/17: The State of the Fisheries (eds. Gaughan, D. J. \& Santoro, K.) 170-174 (Department of Primary Industries and Regional Development, Western Australia, 2018).

21. Henry, G. \& Lyle, J. The National Recreational and Indigenous Fishing Survey. (2003).

22. Cheshire, K., Ward, P., Sahlqvist, P. \& Summerson, R. Monitoring the recreational take of shark species of relevance to Commonwealth fisheries. (2013).

23. Taylor, S. M., Braccini, J., McAuley, R. \& Fletcher, W. J. Review of potential fisheries and marine management impacts on the south-western Australian white shark population. (2016).

24. Pepperell, J. NSW DPI game fish tagging program report 2010-2011. (2011).

25. Last, P. R. \& Stevens, J. D. Sharks and Rays of Australia (Second Edition). (CSIRO Publishing, 2009). 
26. Mitchell, J. D. et al. Quantifying shark depredation in a recreational fishery in the Ningaloo Marine Park and Exmouth Gulf, Western Australia. Mar. Ecol. Prog. Ser. 587, 141-157 (2018).

27. Mcclellan Press, K. et al. Catching sharks: recreational saltwater angler behaviours and attitudes regarding shark encounters and conservation. Aquat. Conserv. Mar. Freshw. Ecosyst. 26, 689-702 (2016).

28. de Faria, F. Recreational fishing of sharks in the Great Barrier Reef World Heritage Area: species composition and incidental capture stress. (MSc thesis, School of Earth and Environmental Sciencies. James Cook University, Townsville, Queensland, 2012).

29. Jones, K. South Australian Recreational Fishing Survey 2007/08. (2009).

30. Pepperell, J. G. Trends in the distribution, species composition and size of sharks caught by gamefish anglers off south-eastern Australia, 1961-90. Aust. J. Mar. Freshw. Res. 43, 213-225 (1992).

31. Young, M., Foale, S. \& Bellwood, D. Impacts of recreational fishing in Australia: historical declines, selfregulation and evidence of an early warning system. Environ. Conserv. 41, 350-356 (2014).

32. DoF. Recreational Fishing in Western Australia - Fish Identification Guide. (2017).

33. DoF. Recreational Fishing in Western Australia - Fishing Location Guide. (2011).

34. Ryan, K. L. et al. An integrated system to survey boat-based recreational fishing in Western Australia 2011/12. (2013).

35. Ryan, K. et al. State-wide survey of boat-based recreational fishing in Western Australia 2013-14. (2015).

36. Ryan, K. et al. Statewide survey of boat-based recreational fishing in Western Australia 2015/16. 205 (2017).

37. Telfer, C. The Western Australian charter boat industry: working towards long-term sustainability. (MSc thesis, School of Natural Sciences. Edith Cowan University, Perth, Western Australia, 2010).

38. R. R Core Team (2018). R: A language and environment for statistical computing. R Foundation for Statistical Computing, Vienna, Austria. URL https://wWw.R-project.org/. (2018).

39. Braccini, M. \& Taylor, S. The spatial segregation patterns of sharks from Western Australia. R. Soc. Open Sci. 3, 160306 (2016).

40. Braccini, M., Molony, B. \& Blay, N. Patterns in abundance and size of sharks in northwestern Australia: cause for optimism. ICES J. Mar. Sci. 77, 72-82 (2020).

41. Gulak, S., de Ron Santiago, A. \& Carlson, J. Hooking mortality of scalloped hammerhead Sphyrna lewini and great hammerhead Sphyrna mokarran sharks caught on bottom longlines. African J. Mar. Sci. 37, 267-273 (2015).

42. Frick, L., Reina, R. \& Walker, T. Stress related physiological changes and post-release survival of Port Jackson sharks (Heterodontus portusjacksoni) and gummy sharks (Mustelus antarcticus) following gill-net and longline capture in captivity. J. Exp. Mar. Bio. Ecol. 385, 29-37 (2010).

43. Gallagher, A., Serafy, J., Cooke, S. \& Hammerschlag, N. Physiological stress response, reflex impairment, and survival of five sympatric shark species following experimental capture and release. Mar. Ecol. Prog. Ser. 496, 207-218 (2014). 
44. Ellis, J. R., McCully Phillips, S. R. \& Poisson, F. A review of capture and post-release mortality of elasmobranchs. J. Fish Biol. 90, 653-722 (2016).

45. Rogers, P. J., Knuckey, I., Hudson, R. J., Lowther, A. D. \& Guida, L. Post-release survival, movement, and habitat use of school shark Galeorhinus galeus in the Great Australian Bight, southern Australia. Fish. Res. 187, 188-198 (2017).

46. Smallwood, C. B., Tate, A. \& Ryan, K. L. Weight-length summaries for Western Australian fish species derived from surveys of recreational fishers at boat ramps. (2018).

47. DPIRD. Annual Report 2019. (2019).

48. Oksanen, J. et al. vegan: Community Ecology Package. R package version 2.5-6. https://CRAN.Rproject.org/package=vegan. (2019).

\section{Tables}

Table 1

Scenarios considered for reconstructed time series of recreational harvest from reported catches of elasmobranch species (or species groups) according to the residential population in Western Australia (base), and additional adjustments for assumed average weight and post-release mortality (low, high).

\begin{tabular}{|lll|}
\hline Scenario & Average weight & Post-release mortality \\
\hline Base case & Table 2 & Table 2 \\
\hline Low & $0.5 \times$ Base Case & $0.5 \times$ Base Case \\
\hline High & $1.5 \times$ Base Case & $1.5 \times$ Base Case \\
\hline
\end{tabular}


Table 2

Relative abundance of elasmobranch species (or species groups) from catches reported by private-boat recreational fishers in state-wide recreational fishing surveys (2011/12, 2013/14, 2015/16 and 2017/18) and charter tour operator logbooks (since 2002) with estimates of average weight and post-release mortality used for reconstructing recreational harvest. Species are sorted by taxonomic order.

\begin{tabular}{llll} 
Common name & Scientific name & Numbers \\
\hline & Retained & Released
\end{tabular}

Carcharhiniformes

Silvertip shark

Carcharhinus albimarginatus

Average weight (kg)

Post-release mortality

Retained Released

\begin{tabular}{|c|c|c|c|c|c|}
\hline Silvertip shark & $\begin{array}{l}\text { Carcharhinus } \\
\text { albimarginatus }\end{array}$ & 0 & 46 & 5.4 & 0.3 \\
\hline Bignose shark & Carcharhinus altimus & 0 & 33 & 5.4 & 0.3 \\
\hline Grey reef shark & $\begin{array}{l}\text { Carcharhinus } \\
\text { amblyrhynchos }\end{array}$ & 15 & 199 & 5.4 & 0.3 \\
\hline Pigeye shark & $\begin{array}{l}\text { Carcharhinus } \\
\text { amboinensis }\end{array}$ & 7 & 7319 & 5.4 & 0.3 \\
\hline Bronze whaler & Carcharhinus brachyurus & 5,639 & 11,956 & 5.4 & 0.3 \\
\hline Spinner shark & Carcharhinus brevipinna & 1,048 & 2,285 & 5.4 & 0.3 \\
\hline Nervous shark & Carcharhinus cautus & 7 & 24 & 4.2 & 0.3 \\
\hline Silky shark & Carcharhinus falciformis & 7 & 11 & 5.4 & 0.3 \\
\hline $\begin{array}{l}\text { Oceanic whitetip } \\
\text { shark }\end{array}$ & $\begin{array}{l}\text { Carcharhinus } \\
\text { longimanus }\end{array}$ & 17 & 830 & 5.4 & 0.3 \\
\hline Blacktip reef shark & $\begin{array}{l}\text { Carcharhinus } \\
\text { melanopterus }\end{array}$ & 827 & 17,178 & 5.4 & 0.3 \\
\hline Dusky whaler & Carcharhinus obscurus & 3,129 & 36,523 & 5.4 & 0.3 \\
\hline Sandbar shark & Carcharhinus plumbeus & 989 & 3,249 & 5.4 & 0.3 \\
\hline $\begin{array}{l}\text { Australian blacktip } \\
\text { shark }\end{array}$ & Carcharhinus tilstoni & 80 & 117 & 5.4 & 0.3 \\
\hline Tiger shark & Galeocerdo cuvier & 199 & 5,920 & 5.4 & 0.3 \\
\hline Sliteye shark & Loxodon macrorhinus & 0 & 3 & 4.2 & 0.3 \\
\hline Lemon shark & Negaprion acutidens & 64 & 2,489 & 5.4 & 0.3 \\
\hline Blue shark & Prionace glauca & 0 & 35 & 5.4 & 0.3 \\
\hline Whitetip reef shark & Triaenodon obesus & 290 & 6,650 & 5.4 & 0.3 \\
\hline $\begin{array}{l}\text { Smooth } \\
\text { hammerhead }\end{array}$ & Sphyrna zygaena & 727 & 2,121 & 5.4 & 0.6 \\
\hline
\end{tabular}




\begin{tabular}{|c|c|c|c|c|c|}
\hline Common name & Scientific name & Numbers & & Average & Post-release \\
\hline $\begin{array}{l}\text { Scalloped } \\
\text { hammerhead }\end{array}$ & Sphyrna lewini & 59 & 906 & 5.4 & 0.6 \\
\hline Gummy sharks & $\begin{array}{l}\text { Mustelus } \\
\text { antarcticus \& M. stevensi }\end{array}$ & 10,433 & 7,240 & 4.2 & 0.1 \\
\hline Whiskery shark & Furgaleus macki & 2,454 & 1,256 & 3.7 & 0.3 \\
\hline School shark & Galeorhinus galeus & 389 & 287 & 4.2 & 0.1 \\
\hline Pencil shark & Hypogaleus hyugaensis & 18 & 2 & 4.2 & 0.3 \\
\hline \multicolumn{6}{|l|}{ Lamniformes } \\
\hline Thresher shark & Alopias vulpinus & 0 & 2 & 5.4 & 0.3 \\
\hline Greynurse shark & Carcharias taurus & 29 & 1,270 & 5.4 & 0.13 \\
\hline \multicolumn{6}{|c|}{ Heterodontiformes } \\
\hline $\begin{array}{l}\text { Port Jackson } \\
\text { shark }\end{array}$ & $\begin{array}{l}\text { Heterodontus } \\
\text { portusjacksoni }\end{array}$ & 138 & 17,715 & 4.2 & 0.05 \\
\hline \multicolumn{6}{|l|}{ Orectolobiformes } \\
\hline Wobbegongs & Orectolobidae & 1,625 & 8,369 & 6.7 & 0.05 \\
\hline Tawny shark & Nebrius ferrugineus & 2 & 199 & 5.4 & 0.3 \\
\hline Zebra shark & Stegostoma fasciatum & 10 & 32 & 5.4 & 0.3 \\
\hline \multicolumn{6}{|l|}{ Squaliformes } \\
\hline Dogfishes & Squalidae & 0 & 1 & 4.2 & 0.3 \\
\hline \multicolumn{6}{|l|}{ Rhinopristiformes } \\
\hline Sawfishes & Pristidae & 18 & 1,489 & 5.4 & 0.3 \\
\hline \multicolumn{6}{|l|}{ Rajiformes } \\
\hline Rays \& skates & Rajidae & 478 & 30,249 & 0.5 & 0.16 \\
\hline
\end{tabular}

\section{Figures}




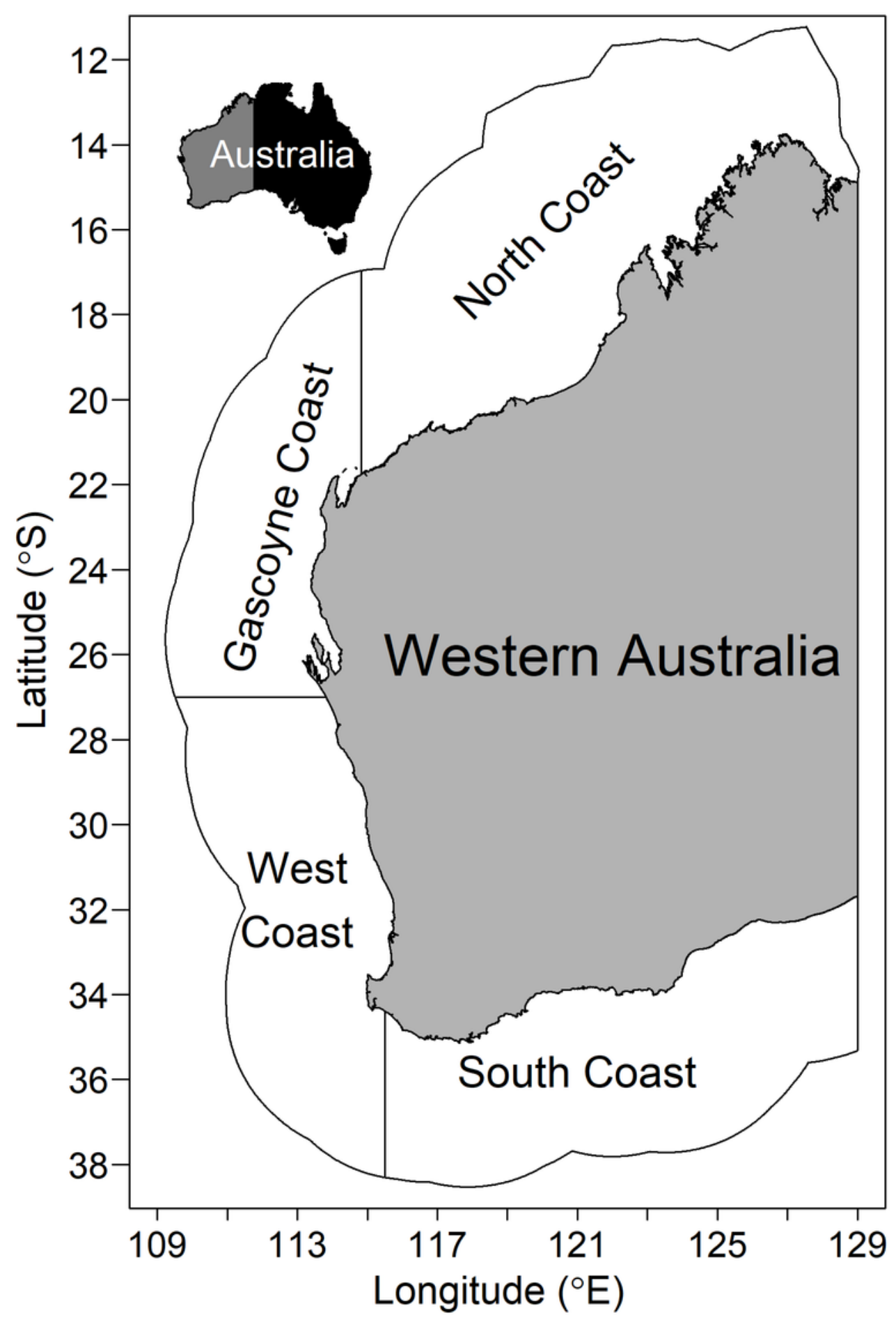

Figure 1

Marine bioregions fished by private-boat recreational fishers and charter tour operators in Western Australia. 


\section{North Coast}

Thresher shark

Tawny shark

Silvertip shark

Silky shark

Sawfishes

Pigeye shark

Oceanic whitetip shark

Dogfishes

Australian blacktip shark

Blacktip reef shark

Whitetip reef shark

Grey reef shark

Scalloped hammerhead

Sandbar shark

Dusky whaler

Lemon shark

Zebra shark

Tiger shark

Gummy sharks

Wobbegongs

Rays \& skates

Bronze whaler

Spinner shark

Greynurse shark

Whiskery shark

Nervous shark

School shark

Pencil shark

Smooth hammerhead

Port Jackson shark

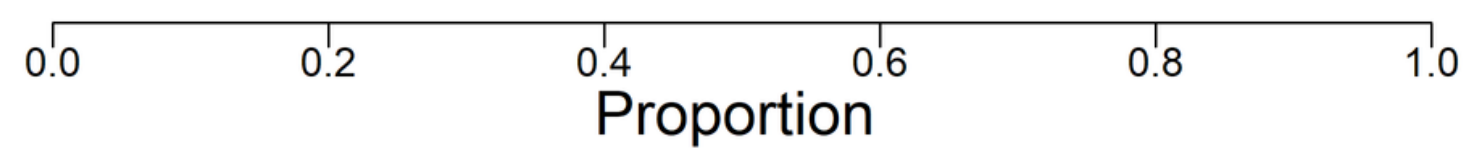

\section{Figure 2}

Proportion of the relative abundance of elasmobranch species (or species groups) among bioregions (private-boat recreational fishers only) in Western Australia for all statewide surveys combined. The total number of individuals is shown on the right-hand side. Species were ordered by bioregion. 


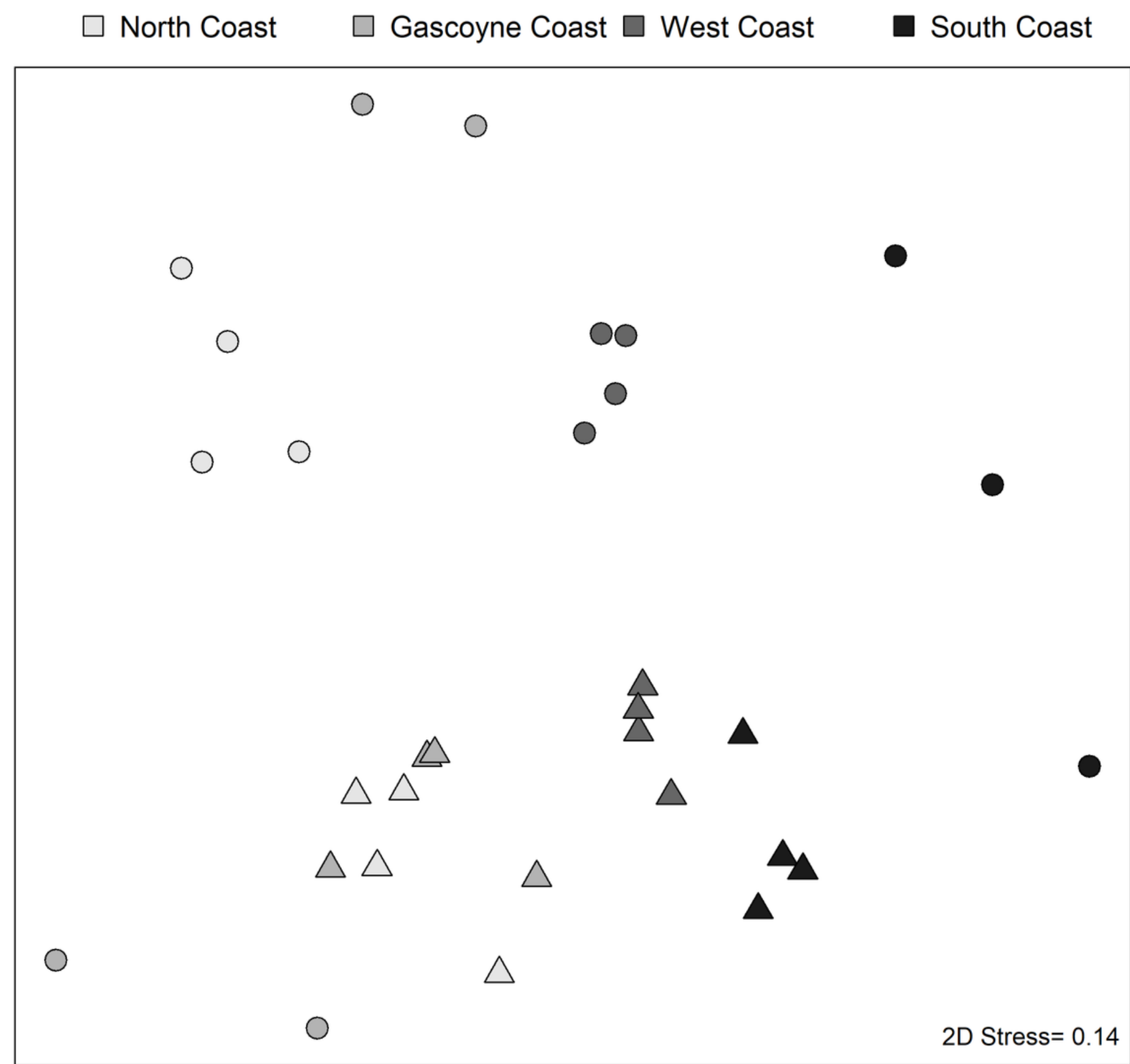

$\triangle$ Private-boat $\bigcirc$ Charter-boat

\section{Figure 3}

Nonmetric multidimensional scaling ordination using square root transformed counts and Bray-Curtis similarities from catches of elasmobranch species (or species groups) reported by private-boat recreational fishers and charter tour operators in Western Australia. Each point denotes a survey type, year and region combination. 
Australian blacktip shark Bignose shark
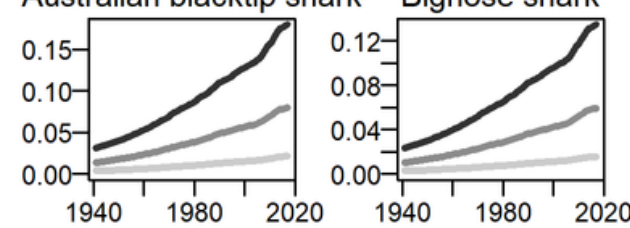

Dusky whaler

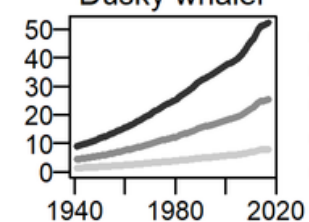

Grey reef shark

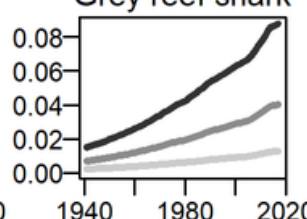

(2) $1940 \quad 1980 \quad 2020$

C) Oceanic whitetip shark Pencil shark
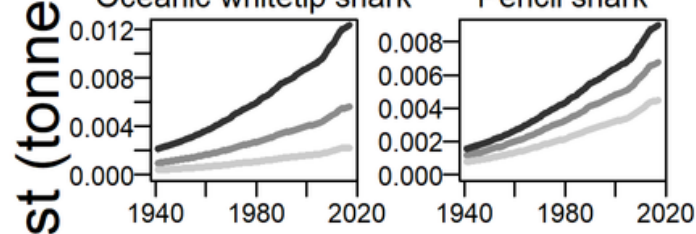

Sawfishes

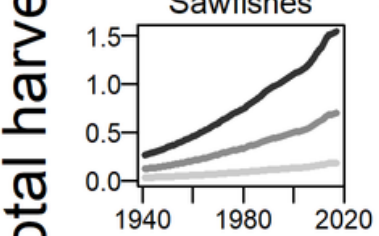

Scalloped hammerhead

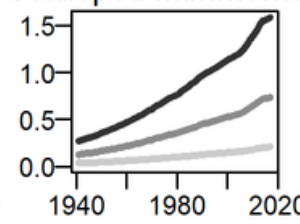

$19401980 \quad 2020$

Smooth hammerhead Spinner shark
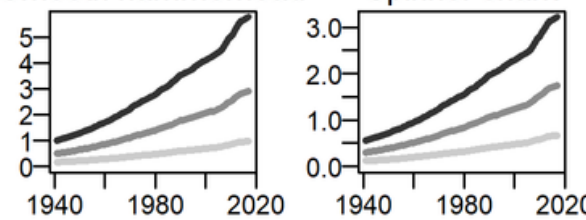

Whitetip reef shark

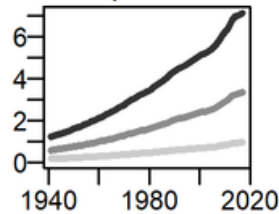

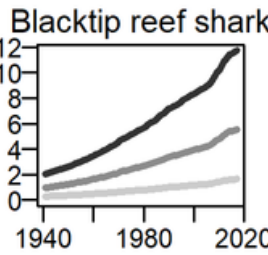
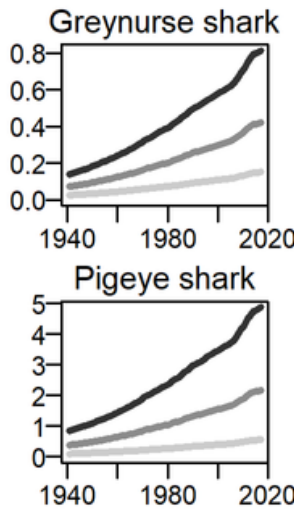

$1940 \quad 1980 \quad 2020$

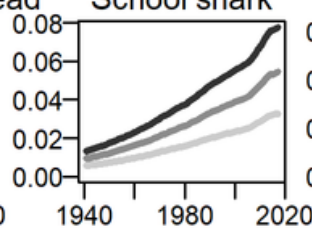

Tawny shark
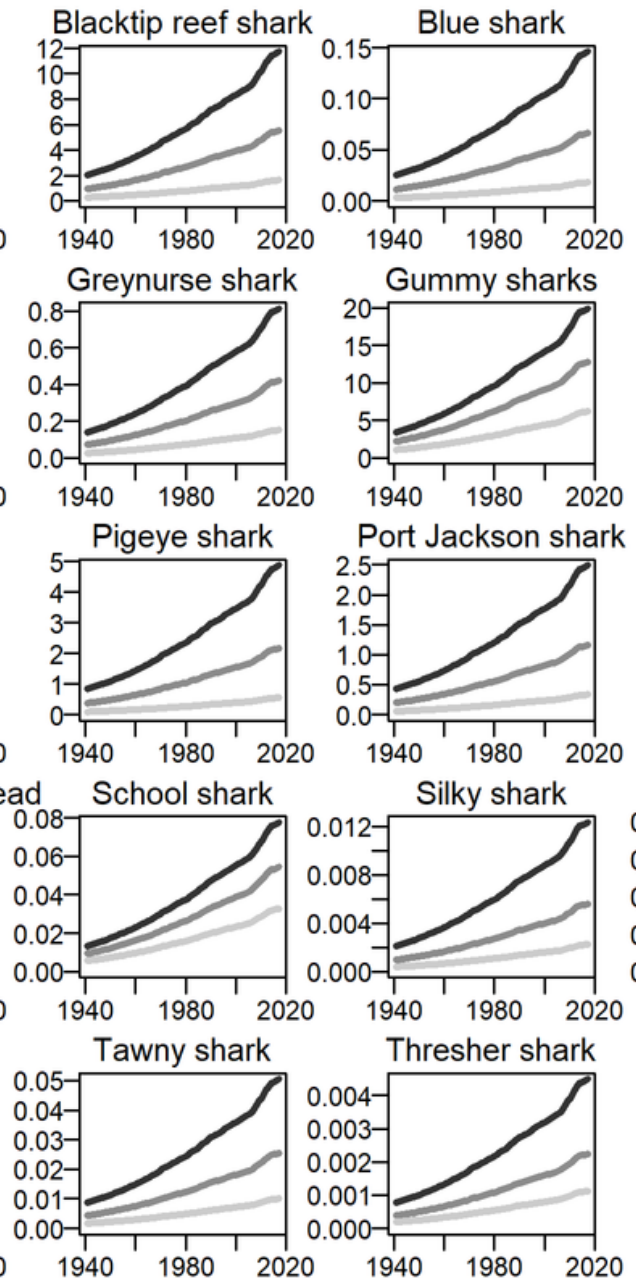

Thresher shark
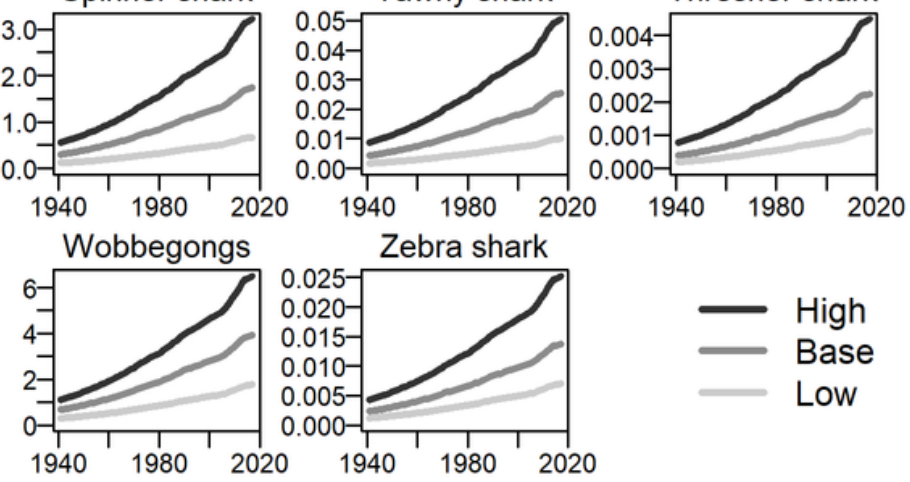

Financial year

High

Base
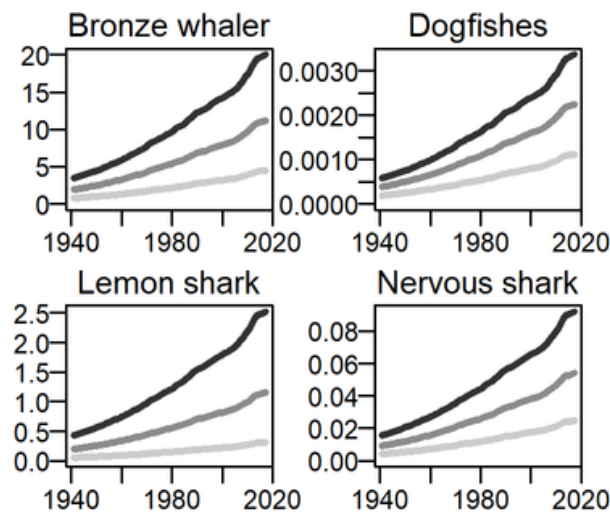

Nervous shark
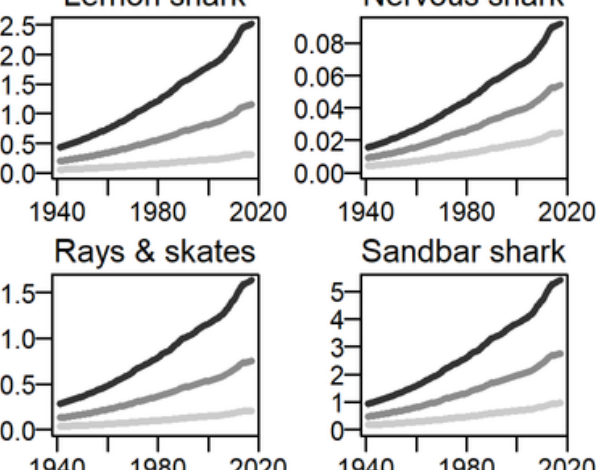

Sandbar shark

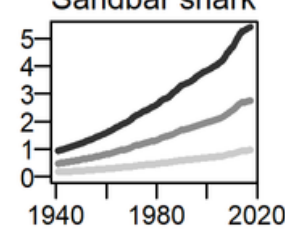

Silvertip shark

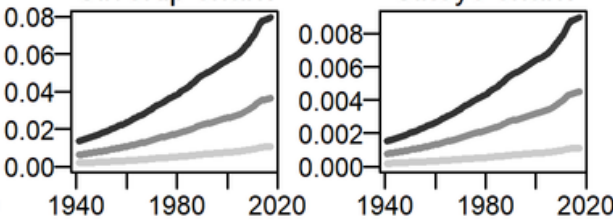

Tiger shark

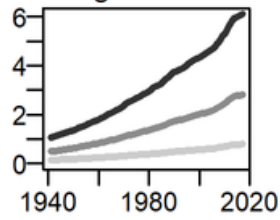

Whiskery shark

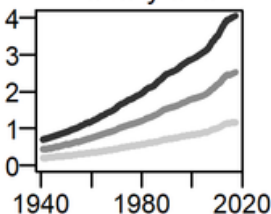

\section{Figure 4}

Reconstructed time series of recreational harvest for elasmobranch species (or species groups) under different assumptions of average weight and post-release mortality. 


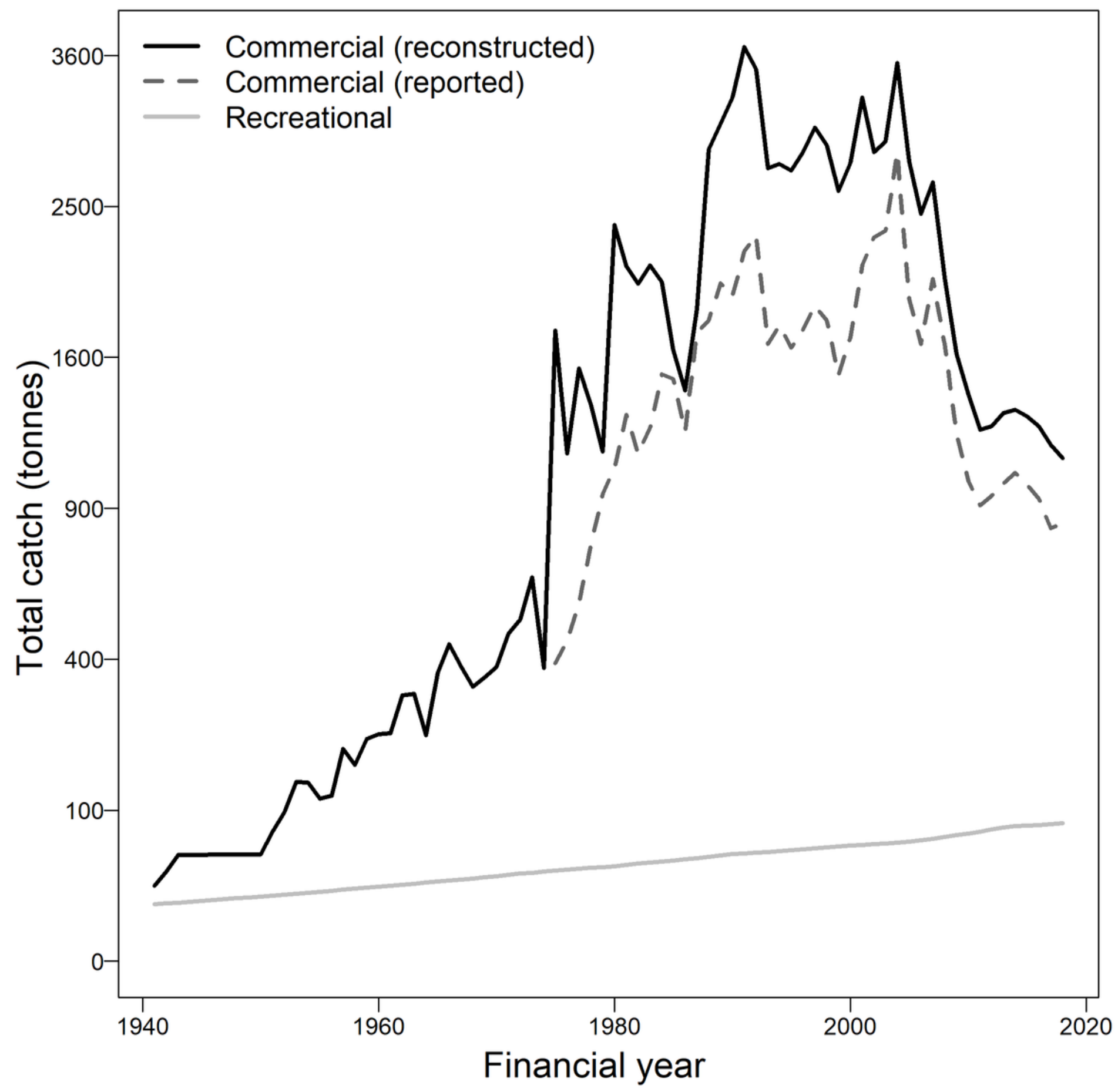

Figure 5

Comparison of time series of commercial and recreational catches. The y-axis was square-root transformed to improve comparisons.

\section{Supplementary Files}

This is a list of supplementary files associated with this preprint. Click to download. 
- SupplementaryInformation.pdf

Page 20/20 